\title{
EVALUASI PENERAPAN SISTEM INFORMASI AKUNTANSI PENJUALAN KREDIT PADA PT.BOSOWA BERLIAN MOTOR (CABANG MANADO)
}

\author{
Angelita R manansal', Ventje A Senduk ${ }^{2}$, Joseph Kambey ${ }^{3}$ \\ Jurusan Akuntansi, Fakultas Ekonomi, Universitas Negeri Manado, Tondano \\ e-mail: manansalangelita@gmail.com¹. sendukventje@unima.ac.id ${ }^{2}$ josephkambey@unima.ac.id $^{3}$ \\ Diterima:6 september 2021 Disetujui: 9 Desember 2021
}

\begin{abstract}
Abstrak
Penelitian ini bertujuan untuk mengetahui dan menganalisis sistem informasi akuntansi penjualan pada PT. Bosowa Berlian Motor Cabang Manado. Metode yang digunakan dalam penelitian ini adalah metode penelitian deskriptif kualitatif dengan teknik analisis data menggunakan teknik analisis deskriptif. Hasil penelitian menunjukkan bahwa kegiatan operasional PT. Bosowa Berlian Motor Manado, terdiri dari tiga kegiatan yaitu penjualan mobil, suku cadang, dan servis. Semua kegiatan tersebut dilakukan dengan memberikan pelayanan yang maksimal kepada pelanggan demi tercapainya tujuan perusahaan menjadi pilihan utama solusi otomotif. Ditemukan bahwa sistem pengendalian intern yang baik, sistem informasi akuntansi penjualan yang diterapkan sudah menggunakan sistem yang terkomputerisasi dengan cukup baik, penerapan sistem informasi akuntansi penjualan kredit telah diterapkan sesuai dengan konsep yang dikemukakan oleh Mulyadi. Prosedur penjualan kredit yang dilakukan oleh perusahaan ini dalam rangka mencapai target atau tujuan umum yang baik dan efektif dalam pelaksanaannya, hal ini dilakukan melalui proses penjualan kredit yang dilakukan oleh setiap karyawan.
\end{abstract}

Kata Kunci: Sistem Informasi Akuntansi, Penjualan, Karyawan

\begin{abstract}
This study aims to determine and analyze the sales accounting information system at PT. Bosowa Berlian Motor Manado Branch. The method used in this study is a qualitative descriptive research method with data analysis techniques using descriptive analysis techniques. The results showed that the operational activities of PT. Bosowa Berlian Motor Manado, consists of three activities, namely car sales, spare parts, and service. All of these activities are carried out by providing maximum service to customers in order to achieve the company's goal of becoming the main choice of automotive solutions. The research was found a good internal control system, the sales accounting information system implemented used a computerized system quite well, and in practice it is in accordance with existing theory and the application of the credit sales accounting information system at PT Bosowa Berlian Motor Manado branch has also been implemented in accordance with the concept proposed by Mulyadi. Credit sales procedures carried out by this company in order to achieve targets or general goals that are good and effective in their implementation, this is done through a credit sales process carried out by each employee.
\end{abstract}

Keywords: Accounting Information System, Sales, Employee 


\section{PENDAHULUAN}

Perkembangan dalam dunia ekonomi saat ini terus mengalami kemajuan. Perkembangan ini terlihat dari setiap perusahaan yang terus melakukan pengembangan terhadap produk serta layanan yang diberikan kepada konsumen. Hal ini tentunya dilakukan untuk memperbanyak konsumen dan konsumen merasa puas dengan produk dan layanan yang diberikan oleh perusahaan. Selain itu, era ini mendorong banyak perusahaan untuk semakin memperluas usahanya dengan meraih pangsa pasar. Hal ini tentunya mendorong terjadinya persaingan antar perusahaan. Perusahaan didirikan dengan tujuan untuk memperoleh keuntungan yang maksimal serta untuk mempertahankan kelangsungan hidup perusahaan itu sendiri. Berdasarkan hal tersebut perusahaan harus memperhatikan beberapa bagian-bagian yang bersifat intern dari perusahaan itu sendiri, seperti sistem yang mengatur setiap proses operasional perusahaan sehingga berjalan secara efisien. Menurut (Mulyadi, 2016), sistem adalah suatu jaringan prosedur yang dibuat menurut pola yang terpadu untuk melaksanakan kegiatan pokok perusahaan. Suatu sistem bisa dikatakan sudah baik apabila telah berjalan sesuai dengan fungsiya dan tidak ada penyimangan didalam sistem tersebut.

Salah satu sistem yang sangat berperan penting dalam perusahaan adalah sistem akuntansi. Sistem akuntansi adalah organisasi formulir, catatan dan laporan yang dikoordinasi sedemikian rupa untuk menyediakan informasi keuangan keuangan yang dibutuhkan oleh manajemen guna memadahk an pengelolaan perusahaan. Sistem akuntansi ini akan menghasilkan informasi keuangan yang berperan penting dalam pengambilan keputusan perusahaan. Formulir atau dokumen, catatan serta laporan ini sebagai bukti yang merekam setiap kegiatan transaksi yang dilakukan oleh perusahaan.

Menurut (Tmbooks, 2015), sistem informasi akuntansi (SIA) meruakan sistem yang menyediakan informasi akuntansi dan keuangan beserta informasi lainnya yang di peroleh dari proses rutin transaksi akuntansi. Sistem informasi akuntansi merupakan komponen yang penting dalam perusahaan dalam mnegumpulkan, mengklasifikasi, mengolah, menganalisa dan memberikan informasi finansial serta pengambilan keputusan yang relevan. Dengan informasi tersebut perusahaan dapat menilai seberapa baik kinerja perusahaan

Salah satu sistem informasi akuntansi yang di perlukan dalam perusahaan adalah informasi penjualan. Sistem informasi ini merupakan seluruh kegiatan penjualan baik tunai maupun kredit yang dilakukan oleh perusahaan. Menurut ( V Wiratna, 2015), sistem penjualan adalah suatu sistem kegiatan pokok perusahaan untuk memperjual-belikan barang dan jasa yang perusahaan hasilkan. Dalam sistem penjualan terdapat dua macam, yaitu sistem penjualan tunai dan sistem penjualan kredit. Dengan adanya sistem informasi akuntansi ini perusahaan dapat mengawasi dan mencatat seluruh kegiatan penjualan perusahaan yang tepat dan akurat dan informasi menyangkut penjualan perusahaan yang nantinya berperan penting dalam pengambilan keputusan. Untuk diperlukan adanya sumber daya manusia yang profesional dan berkompeten dalam menjalankan seluruh aktivitas operasional yang ada dalam sistem penjualan dan penerimaan kas perusahaan.

Sistem penjualan harus didukung dengan adanya suatu sistem komputerisasi yang memadai, dengan adanya sistem komputerisasi ini, seluruh kegiatan operasional perusahaan dapat dikontrol serta diawasi dengan baik terutama menyangkut seluruh kegiatan penjualan perusahaan. Pemahaman sistem yang berbasis komputer sangat penting untuk pengguna, dengan demikian proses pendataan dan pencatatan keuangan perusahaan dapat berjalan dengan baik. Peranan sistem ini sangat membantu pengguna dalam melakukan proses pengelolaan informasi keuangan perusahaan berbasis computer, sehingga penyajian data keuangan yang efisien dan efektif. Sistem informasi akuntansi penjualan sangat penting bagi kelancaran jalannya suatu perusahaan hal tersebut karena melalui sistem informasi pihak managemen dapat mengambil keputusan dengan baik dan tepat serta membantu pengelola perusahaan dalam memenuhi tanggung jawabnya kepada pihak eksternal (Ashar Susanto, 2013). 
Sistem berbasis komputerisasi ini memudahkan dalam menghasilkan informasi dalam bentuk laporan keuangan yang berguna sebagai dasar penelitian dan analisis terhadap kondisi perusahaan. Peranan sistem ini, tidak terlepas dari fungsi yang dijelaskannya. Selain sebagai pengolah data atau memproses data, tetapi sistem informasi akuntansi juga menjalankan fungsi mulai dari pengumpulan data, pengolahan data, pengendalian dan pengolahan data serta fungsi penyedia informasi.

Perusahaan-perusahaan baik yang bergerak dalam bidang jasa, dagang serta manufaktur, tentunya harus menggunakan sistem yang terorganisir dengan baik yang mampu menyediakan informasi menyangkut kegiatan operasionalnya. Sistem ini menunjang dalam setiap kegiatan-kegiatan yang dilakukan perusahaan.dengan adanya suatu sistem perusahaan dapat mengontrol serta mengawasi seluruh kegiatan operasional yang dilakukan perusahaan. Dengan adanya suatu sistem perusahaan dapat mengontrol serta mengawasi seluruh kegiatan operasional yang dilakukan perusahaan.

Sistem penjualan dalam perusahaan dagang begitu penting, karena dalam perusahaan ini kegiatan utama dalam operasionalnya adalah melakukan penjualan produk baik secara tunai maupun kredit. Seluruh kegiatan serta data data penjualan yang dilakukan perusahaan dikelola dalam sistem ini dengan adanya penjualan perusahaan tentunya perusahaan menerima kas dari setiap transaksi penjualan tersebut. Sistem ini memberikan informasi dalam bentuk laporan keuangan menyangkut seluruh aktivitas akuntansi yang berhubungan dengan sistem ini. Informasi ini tentunya menjadi tolak ukur perusahaan dalam kinerja perusahaan dan berperan dalam pengambilan keputusan. Untuk itu, sistem informasi akuntansi untuk penjualan ini harus dikelola dan diawasi dengan baik, sehingga tidak terjadi kesalahan atau masalah - masalah yang nantinya akan berpengaruh dalam sistem, serta tentunya berpengaruh dalam pendapatan perusahaan. Untuk itu, setiap perusahaan harus memiliki suatu sistem pengendalian intern yang baik dalam mengontrol sistem penjualan ini sehingga kegiatan operasional dapat berjalan dengan baik. Pengendalian intern ini biasanya dilakukan oleh pihak - pihak yang mengontrol serta memiliki tanggungjawab yang cukup besar dalam perusahaan, misalnya direktur dan manejer.

Berdasarkan uraian diatas, maka penulis tertarik untuk melakukan penelitian dengan judul "Evaluasi penerapan sistem informasi akuntansi penjualan pada PT Bosowa Berlian Motor Cabang Manado".

\section{Rumusan Masalah}

Berdasarkan latar belakang yang telah diuraikan diatas, maka rumusan masalah dalam penelitian ini adalah bagaimana penerapan sistem informasi akuntansi penjualan pada PT. Bosowa Berlian motor Cabang Manado?

\section{Batasan Penelitian}

Berdasarkan latar belakang di atas maka penelitian ini dibatasi pada sistem informasi akuntansi penjualan pada PT Bosowa Berlian Motor cabang Manado

\section{Tujuan Penelitian}

Tujuan dari penelitian ini adalah untuk mengevalusi penerapan sistem informasi akuntansi penjualan pada PT Bosowa Berlian Motor Cabang Manado.

\section{Landasan Teori}

Suatu sistem pada dasarnya adalah sekelompok unsur yang erat hubungan satu dengan lainnya, yang berfungsi bersama - sama untuk mencapai tujuan tertentu. ( Mulyadi, 2016:2) Dari definisi ini dapat dilihat pengertian lebih lanjut dan lebih umum sebagai berikut. Sistem terdiri dari unsur - unsur, Unsur - unsur tersebut merupakan bagian terpadu sistem yang bersangkutan, Unsur sistem tersebut bekerja sama untuk mencapai tujuan sistem, Suatu sistem merupakan bagian dari sistem lain yang lebih besar.

Sistem akuntansi adalah organisasi formulir, catatan dan laporan yang di koordinasi sedemikian rupa untuk menyediakan informasi keuangan yang dibutuhkan oleh managemen guna untuk memudahkan pengelolahan perusahaan. Dapat dilihat juaga dimana dalam unsur 
suatu sistem akuntansi terdapat formulir, catatan yang terdiri dari jurnal, buku besar dan buku pembantu, serta laporan sebagai berikut (Mulyadi, 2016).

Formulir merupakan dokumen yang digunakan untuk merekan terjadinya transaksi. Formulir sering di sebut dengan istilah dokumen, karena dengan formulir ini peristiwa yang terjadi dalam organisasi direkam (didokumentasikan) di atas secara kertas. Formulir juga sering pula disebut dengan istilah media, karena formulir merupaan media untuk mencatat peristiwa yang terjadi dalam organisasi kedalam catatan. Dengan formulir ini, data yang bersangkutan dengan transaksi direkam pertama kalinya sebagai dasar pencatatan dalam catatan. Dalam sistem akuntansi secara manual, media yang digunakan untuk merekam pertama kali data transaksi keuangan adalah formulir yang dibuat dari kertas, sedangkan dalam sistem akuntansi dengan komputer digunakan sebagai macam media untuk memasukan data kedalam sistem pengolahan data.

Jurnal Merupakan catatan akuntansi pertama yang digunakan untuk mencatat, mengklasifikasikan dan meringkas data keuangan dan data lainnya. Dalam jurnal ini data keuangan untuk pertama kalinya diklasifikasikan menurut penggolongan yang sesuai dengan informasi yang akan di sajikan dalam laporan keuangan. Dalam jurnal ini pula terdapat kegiatan peringkasan data, yang hasil peringkasannya kemudian di-posting kerekening yang bersangkutan dalam buku besar.

Buku besar atau general ledger terdiri dari rekening-rekening yang digunakan untuk meringkas data keuangan yang telah dicatat sebelumnya dalam jurnal. Rekening-rekening dalam buku besar ini dengan unsur-unsur informasi yang akan disajikan dalam laporan keuangan. Rekenig buku besar ini di satu pihak dapat di pandang sebagai wadah untuk menggolongkan data keuangan, di pihak lain dapat dipandang pula sebagai sumber informasi keuangan untuk penyajian laporan keuangan.

Buku Pembantu Jika data keuangan yang di golongkan dalam buku besar diperlukan rinciannya lebih lanjut, dapat di bentuk buku pembantu (subsidiary ledger). Buku pembantu ini terdiri dari rekening-rekening pembantu yang merinci data keuangan yang tercantum dalam rekening tertentu dalam buku besar.

Laporan hasil dari akhir proses akuntansi adalah laporan keuangan yang dapat berupa neraca, laporan rugi laba, laporan perubahan laba di tahan, laporan Yharga pokok produksi, laporan biaya pemasaran, laporan harga pokok penjualan, daftar umur piutang, daftar utang yang akan akan dibayar, daftar saldo persediaan yang lambat penjualannya. Laporan berisi informasi yang merupakan keluaran sistem akuntansi.

Menurut (Wiratna, 2015) penjualan adalah sistem kegiatan pokok perusahaan untuk menjual-belikan barang dan jasa yang perusahaan hasilkan. Dalam sistem penjualan tunai terdapat dua macam, yaitu sistem penjualan tunai dan sistem penjualan kredit.

\section{Pengertian Sistem Informasi Berbasis Komputer}

Menurut (Yakub, 2012) sistem informasi berbasis computer adalah sistem informasi yang menggunakan teknologi computer untuk melakukan beberapa atau seluruh pekerjaan yang diberikan. Sistem informasi berbasis computer juga merupakan sebuah sistem yang terintegrasi. Keuntungan utama dari pemanfaatan sistem informasi berbasis computer ini adalah waktu untuk menghasilkan informasi lebih singkat, disamping birokrasi dapat dikurangi, computer juga berkemampuan proses yang sangat cepat untuk menghasilkan informasi dengan tingkat keakuratan yang tinggi (Oetomo, 2002).

\section{Pengendalian Sistem Informasi Berbasis Komputer}

Menurut (Krismiaji, 2015), pencapaian pengamanan dan pengendalian yang memadai terhadap sumber daya informasi yang dimiliki oleh sebuah organisasi harus menjadi prioritas bagi manajemen puncak. Pengendalian umum dirancang untuk menjamin bahwa seluruh sistem computer dapat berfungsi secara optimal dan pengolahan data dapat dilakukan secara 
lancer sesuai dengan apa yang direncanakan. Pengendalian umum dapat dilakukan dengan cara:

Penyusunan rencana pengamanan, Pemisahan tugas dalam fungsi sistem informasi, Pengendalian proyek penyusunan sistem informasi, Pengendalian akses fisik, Pengendalian akses logis, Pengendalian penyimpanan data, Pengendalian transmisi data, Standar dokumentasi, Meminimumkan penghentian sistem informasi, Rencana pemulihan kerusakan, Perlindungan terhadap computer dan jaringan dan dan Pengendalian internet.

\section{METODE}

Jenis Penelitian yang akan digunakan adalah menggunakan Metode deskriptif kualitatif, yang bertujuan untuk menggambarkan semua data atau keadaan subjek/objek penelitian kemudian dianalisa dan dibandingkan berdasarkan kenyataan yang sedang berlangsung pada saat ini dan selanjutnya mencoba untuk memberikan pemecahan masalahnya. Dalam hal ini, analisis deskriptif berupa pemaparan serta menggambarkan mengenai evaluasi penerapan sistem infomasi akuntansi penjualan dari PT Bosowa Berlian Motor cabang Manado.

Penelitian akan dilaksanakan pada PT Bosowa Berlian Motor cabang Manado. Perusahaan ini merupakan perusahaan otomotif yang menjual kendaraan dari berbagai tipe serta model produk yang dikeluarkan oleh PT Bosowa Berlian Motor Cabang Manado. Penelitian dilaksanakan pada bulan Agustus 2020.

Instrumen penelitian adalah alat bantu yang digunakan dalam metode pengambilan data oleh peneliti dan menganalisa hasil penelitian yang dilakukan dalam langkah penelitian selanjutnya. Instrument penelitian ini dilakukan dengan wawancara tidak terstruktur.

Jenis data yang penulis gunakan untuk penelitian ini adalah jenis data kualitatif, jenis data kulitatif berarti data yang dikumpulkan bukan berupa angka-angka melainkan data tersebut berasal dari wawancara, catatan lapangan, dokumen pribadi, memo, dan dokumen resmi lainnya (Sugiono, 2012). Data yang disajikan berupa kata-kata yang telah dirangkum dalam hasil wawancara langsung kepada pihak yang berkempengtingan pada PT Bosowa Berlian Motor cabang Manado. Data tersebut berupa prosedur-prosedur yang menyangkut dengan penjualan yang dilakukan dalam perusahaan, sistem komputerisasi yang digunakan dalam menungjang proses pengolahan data-data yang diperlukan serta dokumen-dokumen yang terkait didalam aktivitas penjualan pada PT Bosowa Berlian Motor cabang Manado.

Sumber data yang akan dikumpulkan untuk membantu proses penelitian ini yaitu sebagai berikut :

Data Primer : Data primer adalah sumber data yang langsung memberikan data kepada pengumpul data (Sugiono, 2012). Data primer yang diperoleh berasal dari wawancara, data tersebut seperti prosedur sistem informasi akuntansi penjualan pada perusahaan, fungsifungsi dalam melakukan penjualan dan dokumen yang terkait didalam aktivitas sistem serta sistem komputerisasi yang digunakan oleh perusahaan.

Data Sekunder: Data sekunder merupakan sumber yang tidak langsung memberikan data kepada pengumpul data (Sugiono, 2012)). Sumber data sekunder merupakan sumber data yang diperoleh dengan cara membaca, mempelajari dan memahami melalui media lain yang bersumber dari literatur, buku-buku, serta dokumen perusahaan.

Variabel penelitian merupakan segala sesuatu yang berbentuk apa saja yang ditetapkan oleh peneliti untuk dipelajari sehingga diperoleh informasi tentang hal tersebut, kemudian ditarik kesimpulannya (Sugiono, 2014).Didalam penelitian ini variabel yang akan diteiti dalam mengevaluasi sistem informai akuntansi penjualan perusahaan. Sistem informasi akuntansi penjualan yang dimaksud yaitu penggunaan sumber daya manusia dalam menjalankan atau mengoperasikan sistem, prosedur-prosedur yang terkait didalam sistem, penggunaan teknologi yang terpadu dalam menghasilkan informasi menyangkut seluruhb aktivitas operasional dan pengambilan keputusan terkait penjualan dalam perusahaan serta unsur pokok pengendaian intern yang meliputi struktur organisasi yang memisahkan tanggung jawab fungsional yang tegas, sistem wewenang dan prosedur pencatatan yang 
memberikan perindungan yang cukup terhadap kekayaan, hutang, pendapatan dan biaya praktik yang sehat dalam melakukan tugas dan fungsi setiap unit organisasi dan karyawan yang mutuhnya sesuai dengan tanggung jawabnya serta pengendalian sistem yang berbasis komputerisasi.

Metode yang digunakan adalah metode deskriptif yang pengertiannya adalah dalam penelitian ini jenis data yang dikumpulkan adalah data primer dan data se Metode deskriptif adalah suatu metode penelitian yang menggambarkan semua data atau keadaan subjek/objek penelitian kemudian dianalisa dan dibandingkan berdasarkan kenyataan yang sedang berlangsung pada saat ini dan selanjutnya mencoba untuk memberikan pemecahan masalahnya (Restu Kartiko, 2010). Dalam hal ini, analisis deskriptif berupa pemaparan serta menggambarkan mengenai evaluasi sistem informasi akuntansi penjualan dari PT Bosowa Berlian Motor.

\section{HASIL DAN PEMBAHASAN}

PT. Bosowa Berlian Motor adalah salah satu perusahaan yang bergerak di bidang jasa dan perdagangan. PT. Bosowa Berlian Motor yang memiliki berbagai cabang di wilayah tanah air, memulai usahanya dari bawah. Seperti halnya dengan Perusahaan yang sudah maju, Bosowa Berlian Motor yang memiliki berbagai Cabang diwilayah tanah air, memulai usahanya dari bawah. Dengan berbekal keyakinan dan kepercayaan akan masa depan perekonomian Indonesia, Bosowa Berlian Motor untuk pertama kalinya memulai aktifitasnya sebagai dealer mobil tanggal 22 Februari 1973 dengan nama CV. Moneter yang didirikan oleh Bapak H.M. Aksa Mahmud, Putra Bapak H. Mahmud. Hasil perkawinan dengan Hj. Komariah yang Lahir di Barru, Sulawesi Selatan pada Tanggal, 16 Juli 1945 dan pada tanggal itulah ditetapkan sebagai hari Ulang tahun Bosowa.

Dari sinilah kemudian namanya berubah menjadi PT. BOSOWA BERLIAN MOTOR, dengan modal awal Rp 5.000.000,- yang dipinjam dari Bank 1945 Pare-Pare (Bank BNI 45 sekarang).

PT. Bosowa Berlian Motor Cabang Manado adalah salah satu perusahaan dagang dan jasa di kota Manado. PT Bosowa Berlian Motor melayani penjualan mobil merek Mitsubishi, service dan sparepart (suku cadang). PT Bosowa Berlian Motor Cabang Manado memiliki tiga jenis layanan dalam aktivitas operasionalnya yaitu: Penjualan unit kendaraan bermotor (mobil), penjualan suku cadang (Sparepart), Service kendaraan dan pembiayaan.

PT Bosowa Berlian Motor cabang Manado dalam penerapan system informasi akuntansi penjualan sebagaimana yang tercantum di tabel di atas bahwa fungsi penjualan bertanggung jawab untuk menerima order dari pembeli yang menginginkan pembelian kredit sesuai dengan teori yang menyatakan bahwa fungsi penjualan bertanggung jawab menerima surat order dari pembeli. Fungsi kredit PT Bosowa Berlian Motor cabang Manado sesuai dengan teori dimana fungsi kredit PT Bosowa Berlian Motor memiliki salaes area manager dan melaporkan kepada pimpinan sedangkan teori menyatakan fungsi kredit bertanggung jawab meneliti status kredit pelanggan dan memberikan otoritas kredit kepada pelanggan. Fungsi gudang di PT Bosowa Berlian Motor cabang Manado kurang sesuai dikarenakan fungsi gudang mereka membuat surat jalan menjadi bagian administrasi gudang sedangkan menurut teori fungsi gudang hanya menyiapkan dan menyimpan barang yang dipesan pelanggan. Fungsi penagihan sudah sesuai dengan teori karena bertanggung jawab dalam proses penjualan barang begitu juga dengan fungsi akuntansi sudah sesuai dengan teori karena fungsi akuntansi di PT Bosowa Berlian Motor cabang Manado bertanggung jawab dalam pencatatan piutang yang timbul dari penjualan kredit.

\section{Sistem Informasi Akuntansi Penjualan di PT. Bosowa Berlian Motor}

Suatu perusahaan akan berjalan dengan baik apabila terorganisir dan semua bidang terkontrol dengan konesep kinerja dengan baik. Konsep kinerja yang baik itu akan memperoleh hasil yang baik pula dan akan menjadi suatu bahan pertimbangan bagi pimpinan dari suatu perusahaan dalam mengambil keputusan demi kemajuan dan perkembangan suatu 
perusahaan. Oleh sebab itu untuk pengambilan keputusan yang tepat maka diperlukan suatu system informasi akuntansi agar para pemegang saham dan direksi mampu mengambil keputusan dengan baik. Begitu juga yang dilakukan oleh pihak managemen PT. Bosowa Berlian Motor dalam mengambil suatu keputusan dalam penjulalan agar dapat meningkatkan penjulanan dari perusahaan dan mengambil keputusan yang tepat dalam strategi penjualan di perusahaan maka perusahaan menggunakan system infrormasi aktuntansi penjualan dalam membantu kinerja karyawan dan pihak managemen dalam mengambil keputusan.

\section{Fungsi yang terkait dalam system infromasi akuntansi penjualan di PT. Bosowo BErlian Motor Manado}

Fungsi Sales/Pesanan Penjualan yaitu Menerima pesanan atau order dari pelanggan, membuat surat pesanan kendaraan (SPK), mengurus berkas - berkas pelanggan, membuat daftar pesanan. Fungsi Kredit yaitu Bertanggung jawab untuk meneliti status kredit pelanggan dan memberikan otoritas pemberian kredit kepada pelanggan. Fungsi Kasir/Accounting yaitu Bertanggung jawab untuk menerima pembayaran dari pelanggan serta menyiapkan kwitansi dan bertanggung jawab menyetor uang kas perusahaan ke bank. Fungsi Administrasi Sales yaitu Membuat Sales Order (SO), Delivery Order (DO), Faktur Penjualan, Mengajukan Good Issue (Gl) ke pusat untuk mengeluarkan faktur kendaraan dan membuat surat - surat kendaraan. Fungsi Gudang yaitu Berfungsi untuk menjalankan tugas meyiapkan kendaraan yang dipesan oleh pelanggan.

\section{Prosedur Penjualan dalam system informasi akuntansi penjualan di PT.Bosowa Berlian Mandiri Motor}

Dimulai dari bagian Sales Pesanan Penjualan, Penerima Order diawali dengan kedatangan calon konsumen ke showroom PT. Bosowa Berlian Motor Manado atau konsumen menghubungi salesman. Sales menawarkan barang, dan konsumen akan melakukan pemilihan dan pemesanan barang yang disebut prosfek. Ketika sudah terjadi kesepakatan antara kedua belah pihak, sales membuat Surat Pesanan Kendaraan (SPK) sesuai kualifikasi kendaraan yang dipilih oleh konsumen. SPK dibuat sebanyak 2 rangkap, rangkap 1 untuk PT. Bosowa Berlian Motor rangkap 2 pelanggan Surat Pesanan Kendaraan (SPK) akan ditanda tangani oleh konsumen dan kepala bagian penjualan. Sebelum sales melakukan pemesanan barang, sales meminta dokumen - dokumen pendukung pengajuan kredit untuk diberikan kepada bagian kredit. Dokumen yang dimaksud ialah fotocopy KTP, fotocopy Kartu Keluarga, fotocopy NPWP fotocopy Rekening Listrik, fotocopy Buku Tabungan tiga bulan terakhir, fotocopy Surat keterangan Usaha / Kerja, fotocopy Slip gaji, bagi PNS dan karyawan swasta fotocopy Surat keterangan usaha. Bagian Kredit menerima dokumen - dokumen dan memeriksa, serta melakukan survey terhadap konsumen apakah layak untuk mendapatkan pembiayaan kredit. Ketika bagian kredit sudah memproses dan sudah memenuhi syarat maka bagian kredit akan memasukkan data konsumen kedalam sistem dan mencetak Purchasing Order (PO) untuk kelanjutan proses pemesanan barang. Jika hasil pemeriksaan berkas dan hasil survey tidak disetujui maka berkas dari konsumen dibekukan. Setelah Purchasing Order (PO) dikeluarkan, maka dilakukan proses pembayaran Down Payment (DP) di bagian kasir, disertai dengan memasukkan dokumen Purchasing Order (PO), fotocopy KTP, fotocopy Kartu Keluarga, fotocopy Rekening Listrik, fotocopy Tabungan 3 bulan terakhir, fotocopy Surat keterangan Usaha / Kerja, fotocopy Slip gaji, bagi PNS dan karyawan swasta fotocopy Surat keterangan usaha, fotocopy NPWP, Surat Pesanan Kendaraan (SPK) rangkap 1. Bagian kasir menerima uang Down Payment (DP), kemudian menginput ke sistem yang digunakan oleh perusahaan yaitu BAMS (Bosowa Automative Management System. Selanjutnya mencetak kwitansi sebanyak 3 (tiga) rangkap, dimana rangkap 1 diberikan kepada pelanggan, rangkapa 2 diarsip oleh bagian kasir, dan rangkap 3 untuk syarat pembuatan Sales Order (SO), Delivery Order (DO) dan faktur penjualan. Uang yang diterima diserahkan oleh kasir ke petugas bank untuk dimasukkan kedalam rekening perusahaan. Kemudian Purchasing Order (PO), kwitansi 3, Surat Pesanan Kendaraan (SPK) 1 , fotocopy KTP, fotocopy Kartu Keluarga, fotocopy Rekening Listrik, fotocopy Tabungan 3 bulan terakhir, fotocopy Surat keterangan Usaha / 
Kerja, fotocopy Slip gaji, bagi PNS dan karyawan swasta fotocopy Surat keterangan usaha. fotocopy NPWP diberikan ke bagian administrasi sales untuk pembuatan Sales Order (SO), Delivery Order (DO) dan faktur penjualan. Kemudian Sales Order (SO), Delivery Order (DO) dan faktur penjualan. Dilanjutkan kebagian gudang. Bagian administrasi sales melakukan arsip untuk dokumen yaitu fotocopy buku tabungan, Rekening Listrik, Purchasing Order (PO), fotocopy slip Gaji, atau fotocopy Surat usaha (untuk Swasta), dan Surat pesanan kendaraan (SPK). Bukti Serah Terima Kendaraan, Sales Order (SO), dan Delivery Order (DO), fotocopy Kartu Tanda Penduduk (KTP), kemudian diserahkan kebagian administrasi sales, dengan adanya dokumen ini bagian administrasi sales akan melakukan proses pengajuan faktur ke PT. Mitsubishi Motors Krama Yudha Sales Indonesia Good Issue (GI) lewat email, Setelah faktur dikeluarkan maka faktur kendaraan tersebut digunakan untuk pengajuan ke bidang permohonan surat kendaraan bermotor (PSKB) untuk pembuatan Surat Tanda Nomor Kendaraan (STNK) dan Bukti tanda pemilik kendaraan Bermotor (BPKB). Bagian administrasi sales melakukan pengarsipan untuk Bukti Surat Tanda Kendaraan (BSTK), Sales Order (SO), dan Delivery Order (DO), fotocopy Kartu Tanda Penduduk (KTP). Jika Surat Tanda Nomor Kendaraan (STNK) dan Bukti tanda pemilik kendaraan Bermotor (BPKB), telah selesai maka STNK diserahkan kepada pemilik atau pelanggan dan BPKB serta Faktur Kendaraan diserahkan kebagian Finance untuk jaminan pelunasan kredit. Kemudian Prosedur Selesai.

PT Bosowa Berlian Motor merupakan perusahaan otomotif serta merupakan salah satu merek kendaraan beroda empat yang di pasaran saat ini. Persaingan antara perusahaan otomotif yang saat ini cukup ketat dalam hal ini menyangkut penjualan dari masing - masing merek.

Dalam melakukan penjualan unit kendaraan PT Bosowa Berlian Motor cabang Manado tidak dapat langsung menyetujui pesanan dari customer. Terdapat tahap-tahap atau prosedur yang harus dilakukan sebelum menyerahkan unit kepada customer. Customer harus memenuhi beberapa syarat yang diterapkan oleh perusahaan seperti pembayaran unit. Pembayaran ini dapat dilakukan dengan cash dan dengan pengajuan kepada leasing/pembiayaan. Sebelum unit dikirim kepada customer perusahaan harus memastikan kelengkapan dokumen dan customer telah memenuhi seluruh syarat yang diterapkan oleh perusahaan menyangkut penjualan.

Dalam sistem penjualan PT Bosowa Berlian Motor cabang Manado terdiri dari beberapa prosedur yang wajib untuk dilakukan oleh customer maupun seluruh fungsi yang terkait sebelum mengirimkan unit dan customer menerima unit tersebut. Seluruh kegiatan operasional perusahaan ditunjang dengan adanya sistem terkomputerisasi. Sistem komputerisasi yang digunakan adalah Dealer Management System. Setiap fungsi atau bagian menggunakan sistem komputerisasi ini dalam pengolahan data serta dalam pembuatan dokument - dokumen yang digunakan dalam menunjang kegiatan penjualan perusahaan. Sistem penjualan dapat berjalan dengan baik apabila terdapat pengendalian intern yang baik dari perusahaan.

System informasi akuntansi penjualan yang diterapkan oleh PT. Bosowa Berlian Motor Manado sangat menunjang pelaksanaan pengendalian inern penjualan di perusahaan. System informasi akuntansi penjualan yang digunakan oleh PT. Bosowa Berlian Motor Manado mampu meningkatkan pelaksanaan pegendalian intern dalam pengambilan keputusan penting demi kemajuan dan perkembangan perusahaan. Informasi yang disampaikan akurat, relvan, dan tepat waktu. System informasi akuntanis yang digunakan adalah system informasi komputerisasi secara online yakni dimasukan kedalam system informasi perusahaan Bosowa Dealer Administrasion Managemen Service dan system yang digunakan berdasarkan unsur-unsur system informasi akuntansi penjualan.

Input, PT. Bosowa Berlian Motor Manado menggunakan sisten informasi akuntansi penjulana dengan memberikan dengan memberikan kwitansi pembayaran oleh Kasir yang berisikan tanggal pembayaran, jumblah yang diterima, siapa yang membayar dan siapa yang menerima. 
Bukti pembayaran tersebut dikeluarkan ketika semua berkas pembelian barang diterima oleh Barans Manager dan disahkan.

Model , PT. Bosowa Berlian Motor Manado dalam system informasi penjualannya pihak sales dan kasir bekerja sama dengan adminstrasi sales dan adiminstrasi spearpak untuk menginput seluruh penjualan dalam 3 bulan berjalan dan kemudian dimasukan dalam sisten komputersisasi pada program $B A M S$

Output, System informasi akuntansi penjualan yang ada di PT. Bosowa Berlian Motor manado seperti laporan keuangan, dan laporan penjualan yang dibuat oleh Head Administration, Administrasi Sales, Administrasi Sperpak dan accounting dalam bekerjasama dengan bidng keuangan yakni casir bibuat dan dimasukan secara komputersiasi kedalam system informasi Bosowa Dealer Managemen Service dan dilaporakan secara online agar dapat diakses oleh konsumen dan pihak direksi dari PT. Bosowa Berlian Motor.

Teknologi, PT. Bosowa Berlian Motor dalam sisten informasi Akuntansi penjulan menggunakan system komputerisasi secara offline maupun online. Data-data laporan keuangan dan penjualan dari perusahaan secara terperinci dimasukan kedalam system komputerisasi dan dapat diakses oleh pihak direksi melalui Bosowa Dealer Administrasion Managemen Service (BAMS).

Basis data, Seluruh data-data system informasi akuntasni penjualan di PT. Bosowa Berlian Motor di masukan dalam system Bosowa Dealer Administration Managemen Service. Melalui system tersebut pihak managemen dan karyawan dapat mengakses seluruh informasi keuangan dan penjualan di perusahaan PT. Bosowa Berlian Motor dan perkembangan serta kesehatan keuangan perusahaan.

Pengendalian, Beberapa cara yang dilakukan oleh PT. Bosowa Berlian Motor dalam melindungi informasi akuntansi penjualan yakni:

Fungsi pengendalian interen dalam sisten informasi akuntansi penjulanan di PT. Bosowa Berlian

Berdasarkan pembahasan diatas, fungsi yang dilakukan dan ditemukan dilapangan yakni: Fungsi pernjualan, Pada sistem Informasi akuntansi penjualan intern yaitu bertanggungjawab pada penjulan dan menerima order dari pembeli yang menginginkan secara kredit yakni bidang Sales. Fungsi kredit yaitu dalam sistem informasi pada PT. Bosowa Berlian Motor cabang Manado yaitu untuk meneliti status kredit pelanggan dan dilakukan oleh Sales Area Manager. Fungsi gudang, Pada sistem di PT. Bosowa Berlian Motor Manado, fungsi gudang untuk menyimpan dan menyediakan barang yang dipesan dan dilakukan oleh administrasi gudang. Fungsi pengiriman, Di PT. Bosowa Berlian Motor Cabang Manado fungsi pengiriman bertanggungjawab untuk penyerahan barang berdasarkan nota barang yang dikeluarkan oleh admin gudang. Fungsi akuntansi, di PT. Bosowa Berlian Motor Cabang Manado yakni bertanggungjawab untuk mencatat piutang dan penerimaan barang dari pendapatan dan penjualan.

\section{KESIMPULAN DAN SARAN}

Dapat diambil kesimpulan dari hasil dan pembahasan yaitu sebagai berikut: Kegiatan operasional PT. Bosowa Berlian Motor Manado, terdiri atas tiga aktifitas yaitu Penjualan mobil, Sparepart, dan Jasa Service. Semua kegiatan itu dilakukan dengan memberikan pelayanan semaksimal mungkin kepada pelanggan guna mencapai tujuan dari perusahaan untuk menjadi pilihan utama dalam solusi otomotif. Sistem pengendalian internal sudah baik karena berdasarkan empat unsur yang dikemukakan oleh Mulyadi PT. Bosowa Berlian Cabang Manado sudah memenuhi keempat unsur tersebut.

System informasi akuntansi penjualan yang diterapkan oleh PT Bosowa Berlian Motor cabang Manado telah menggunakan system komputerisasi dengan cukup baik, dan di dalam prakteknya sudah sesuai dengan teori yang ada. Penerapan system informasi akuntansi 
penjualan kredit pada PT Bosowa Berlian Motor cabang Manado juga telah dilaksanakan sesuai dengan konsep-konsep yang dikemukakan oleh mulyadi. Dari prosedur order penjualan sampai melibatkan fungsi-fungsi yang terkait, dan dokumen-dokumen yang digunakan.

Prosedur penjualan kredit yang dilakukan oleh perusahaan ini guna mencapai target atau tujuan umumnya sudah baik dan efektif dalam pelaksanaanya, hal ini dilakukan lewat proses penjualan kredit yang di jalankan oleh setiap karyawan.

Dari hasil penelitian yang telah dilakukan oleh penulis, maka system infromasi akuntansi penjualan adakan efektik dilakukan oleh perusahan dan perkembangan penelitian selanjutnya akan lebih baik dan optimal apabila.

Perusahaan hendaknya memperhatikan perkembangan teknologi yang dapat mempermuda dan memperbaharui sistem informasi akuntansi di PT. Bosowa Berlian Motor cabang Manado. Untuk mempermuda konsumen dalam pembayaran kredit, hendaknya perusahaan memanfaatkan proses pembayaran dengan menggunakan kartu kredit dari pihak BANK yang telah bekerja sama dengan perusahaan PT. Bosowa Berlian Motor Cabang Manado. Bagi peneliti selanjutnya agar bisa dapat memperluas penelitian agar memperoleh hasil yang lebih optimal

\section{DAFTAR PUSTAKA}

Asriyani, D. W., Halim, M., \& Nastiti, A. S. 2020. Evaluasi Penerapan Sistem Informasi Akuntansi Penerimaan Kas Bagian Unit Rawat Jalan. BUDGETING: Journal of Business, Management and Accounting, 2(1), 79-88.

Bosowa Berlian Motor. 2008. Logo Perusahaan. https://bosowaberlian.co.id.

Bosowa Berlian Motor. 2008. Profil dan Sejarah Perusahaan. https://bosowaberlian.co.id.

Baramuli, J., \& Karamoy, H. 2014. Evaluasi penerapan sistem informasi akuntansi penjualan pada PT. Ciputra Internasional Manado. ACCOUNTABILITY, 3(1), 23-31.

Devita. "Wawancara tentang prosedur penjualan kredit unit kendaraan mobil pada PT. Bosowa Berlian Motor Cabang Manado." Manado 2020.

Fengky, H., Sabijono, H., \& Kalalo, M. 2019. Evaluasi penerapan sistem pengendalian internal penerimaan kas pada Hotel Yuta Manado. Jurnal EMBA: Jurnal Riset Ekonomi, Manajemen, Bisnis dan Akuntansi, 7(1).

Hall, James A. 2009, Sistem Informasi Akuntansi. Edisi 4. Salemba Empat: Jakarta.

HERDIYANTORO, R. 2015. Evaluasi Penerapan Sistem Informasi Akuntansi Penjualan Kredit Pada Pt." X" Di Surabaya (Jurnal Akuntasni Internasional, Universitas Airlangga).

Hecca Mitra Utama. 2014. Penjualan dan penerimaan kas berbasis computer pada perusahaan kecil (studi kasus PT Trust Teknologi). Jurnal skripsi fakultas ekonomi universitas sriwijaya. Hal (45-55).

Hartono, Jogianto.2013. Metode Penelitian Bisnis. BPFE:Yogyakarta

Krismiaji, 2015 Sistem Informasi Akuntansi. UPP STIM YKPN : Yogyakarta.

Krisnawati et al. 2013. Analisis system informasi akuntansi penjualan dan penerimaan kas pada PT telekomunikasi Indonesisa Tbk, Kandatel Malang. JAB vol 1 no 1 april 2013. Hal (59-67).

Kintan Viktorina. 2020. Evaluasi penerapan system informasi akuntansi penjualan kredit pada PT. Jumbo Power Internasional.

Lumanaw, K. R., \& Tinangon, J. 2016. Evaluasi Penerapan Sistem Informasi Akuntansi Penggajian untuk Pengendalian Intern pada PT. BPR Danaku Mapan Lestari di Kota Bitung. Jurnal EMBA: Jurnal Riset Ekonomi, Manajemen, Bisnis dan Akuntansi, 4(2).

Mulyadi, 2016. Sistem Informasi Akuntansi, salemba Empat : Jakarta

Mujahidah et.al. 2016. Analisis system informasi akuntansi penjualan pada PT Hadji Kalla Cabang Pinran. Jurnal akuntansi vo 1 no 020. Ha (166-180) 


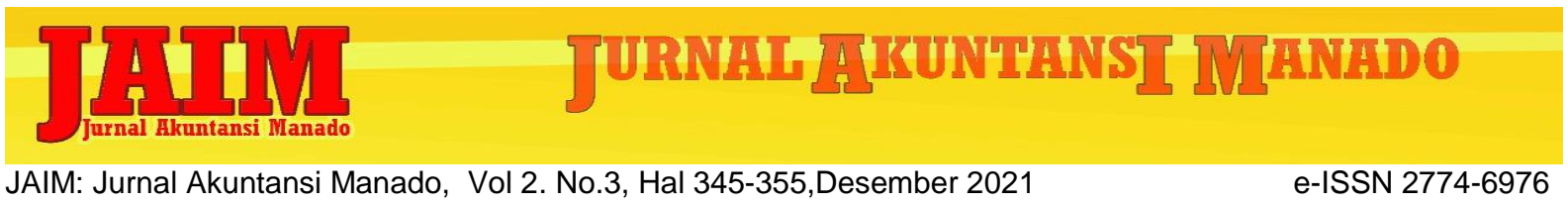

Maria, D. (2013). Pengaruh Modernisasi Sistem Administrasi Perpajakan Terhadap Tingkat Kepatuhan Pengusaha Kena Pajak Di Kantor Pelayanan Pajak (Kpp) Pratama Bandar Lampung. 01(01).

Nurlaila, I. 2017. Evaluasi penerapan sistem informasi akuntansi dan sistem pengendalian internal pada persediaan barang jadi di Pt. Iskandar IndahPrinting Textil surakarta. Skripsi. Surakarta: Intitut Agama Islam Negeri Surakarta.

Oetomo, B S Dharma.2002. Perencanaan dan Pembagunan Sistem Informasi. Penerbit Andi : Yogyakarta.

Purba, M. A., Purba, D. H., Jamaluddin, J., \& Silalahi, M. P. 2021. EVALUASI PENERAPAN SISTEM INFORMASI AKUNTANSI PERSEDIAAN BAHAN BAKU PADA PT. CIOMAS ADISATWA MEDAN. METHOMIKA: Jurnal Manajemen Informatika \& Komputerisasi Akuntansi, 5(1), 77-80.

Reeve, James; Carl S Warren; Johnatan E Durhac; Ersha T Wahyudi; Gatot Soeprianto; Amir Abadi Jusuf; Chaerul D Djakman. 2011. Pengantar Akuntansi. Buku Satu. Salemba Empat : Jakarta.

Sugiono, 2014. Metode penelitian Bisnis. Alfabeta : Bandung

Sujarweni, V Wiratna. 2015. Sistem Akuntansi. Pustaka Baru Press : Yogyakarta.

Sutabri, Tata 2012. Konsep Sistem Informasi. Andi : Yogyakarta.

Sutabri, Tata 2004, Sistem Informasi Akuntansi. Andi : Yogyakarta

Kalla cabang Pinrang. Jurnal akuntansi vol 1 no 020. Hal (166-180).

Tmbooks, 2015, Sistem Informasi Akuntansi, Andi Offset : Yogyakarta

Tommy L.H. Tumalun. 2019 Analisis system informasi akuntansi penjualan kredit di PT Nusantara Sakti Cabang Manado.

Tullah, R., \& Hanafri, M. I. 2014. Evaluasi penerapan sistem informasi pada Politeknik LP3I Jakarta dengan metode PIECES. Jurnal Sisfotek Global, 4(1).

Viola et.al. 2017. Analisis dan perancangan system informasi akuntansi penjulan dan persediaan. Jutei edisi voleme 1 no. 2 Oktober 2017. Hal (153-162).

Viktorina, K., Sabijono, H., \& Pinatik, S. 2020. EVALUASI PENERAPAN SISTEM INFORMASI AKUNTANSI PENJUALAN KREDIT PADA PT. JUMBO POWER INTERNATIONAL. GOING CONCERN: JURNAL RISET AKUNTANSI, 15(4), 534-540.

Wati, A. M. P., Kristianto, D., \& Sunarko, M. R. 2017. EVALUASI PENERAPAN SISTEM INFORMASI AKUNTANSI PENERIMAAN KAS ORGANISASI NIRLABA (Studi Kasus pada Lembaga Amil Zakat Nasional Nurul Hayat Cabang Solo). Jurnal Akuntansi dan Sistem Teknologi Informasi, 12(4).

Widi Kartiko Restu, 2010 Asas Metodelogi Penelitian, Graha IImu : Yogyakarta.

Yakub, 2012. Pengantar system informasi, edisi pertama raha ilmu : Yogyakarta. 